\title{
Neem relative growth under supplementary irrigation with saline waters and biofertilizer
}

Francisco de Oliveira Mesquital", Lourival Ferreira Cavalcante'2, Francisco Xavier de Oliveira Filho3, Rummenigge de Macêdo Rodrigues², Vinícius Batista Campos ${ }^{4}$, Jânio Kleiber Camelo de Souza ${ }^{5}$

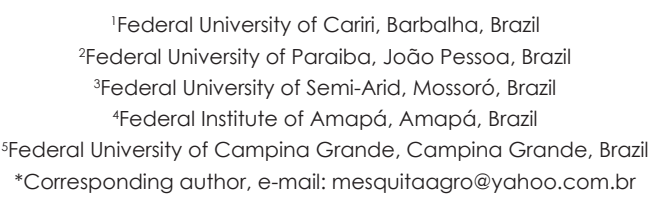

\begin{abstract}
An experiment was performed, during the period from January to July, 2016, in a screened environment of the Department of Soils and Rural Engineering of the Agrarian Sciences Center, Federal University of Paraiba (UFPB), Areia, Paraiba, Brazil, with the purpose of evaluating the effects of supplementary irrigation with saline waters over the relative growth of Indian neem seedlings, in soil with bovine biofertilizer. The substrate used was a dystrophic Yellow-Red Latosol. The experimental design was in randomized blocks, with four replications, in a $5 \times 2 \times 3$ factorial scheme, referring to the water salinity levels of $0.5,1.5,3.0,4.5$ and $6.0 \mathrm{dS} \mathrm{m}^{-1}$, in soils without and with bovine biofertilizer, and in three evaluation periods: at 90,120 and 180 days after emergence of the seedlings, in order to evaluate the relative growth rate of the studied morphological parameters, evaluated by the relation of the periods from 90 to 120 and 120 to 180 DAE of the plants in height, stem diameter, root dry matter, dry matter of the aerial part and total (root + aerial part) dry matter. The growth of the neem seedlings was compromised by the degenerative action of the salts of the irrigation water, but with lower severity in those plants of the treatments with the bovine biofertilizer.
\end{abstract}

Keywords: Azadirachta indica A. biofertilization, salinization

\section{Introduction}

The Indian neem (Azadirachta indica A. Juss) belongs to the Meliaceae family, being an exotic, leafy plant, of fast growth and persistence to hydric deficit (Maithani et al., 2011; Klippel al., 2013). The extract from leaves and seeds exercises bioinsecticide action in the control of agricultural pests (Neves \& Carpanezzi, 2008); the plant is also utilized in the production of cutting wood and firewood as energy source for ceramics production, in the fabrication of roof tiles and bricks, in replacement to traditional species of importance in the Brazilian Caatinga biome (Medeiros et al., 2017). In addition to these advantages, the plant positively contributes to the recovery of physically degraded areas (Debashri et al., 2012).

The plants under natural conditions are subjected to several environmental changes, presenting, as consequences, a series of stimulations that influence in the germination, emergence, growth, development and production of the plants. The factors which originate stress during the initial growth of the neem include those originated from the action of living organisms, anthropogenic activities, climatic changes, shortage or excess of water, excessive light intensity, nutrients deficiency and water and soil salinity (Katerji et al., 2011).

The production of high-quality seedlings 
demands a rigid methodologic criterium, biological material from qualified sources and low production cost (Dutra et al., 2012). In this phenological stage, the neem, during the first year, is moderately tolerant to salinity (Isla et al., 2014) and, therefore, might have is growth inhibited by the salinity or sodicity of the irrigation water (Mesquita et al., 2015).

The basis of the growth analysis is based on the fact that, virtually, all the accumulated organic matter throughout the plant development is resultant of photosynthetic activity. In this manner, the accumulation of dry matter and the increment of the leaf area, quantified as a function of time, are utilized in the estimation of several physiological indices related to the differences of development among cultivars (Lima et al., 2007).

The process of growth decrease, in some plants, might be resulted from the elevated saline level in the irrigation water, affecting the ionic balance, the nutritional and phytohormonal composition, physiological processes, biochemical reactions (Munns \& Tester, 2008) or even reducing the photosynthetic and growth rates (Sucre \& Suares, 2011 )".

Under elevated saline conditions, according to Yang et al. (2011), it is hard to cultivate or to increase the productivity of several crops in periods of drought and high temperatures. An attempt for reducing this inconvenience has been the employment of some organic inputs, among them the common bovine biofertilizer, provided for the soil in liquid form (Medeiros et al., 2013; Mesquita et al., 2017).

Considering that the neem is distributed into almost all cities of Brazil as an ornamental plant, it is an invasive plant in several degraded or nondegraded areas, being cultivated in the states of Bahia, Ceara, Paraiba, Pernambuco, Piaui and Rio Grande do Norte (Neves \& Carpanezzi, 2008; Medeiros et al., 2017); it is also utilized in the recovery of physically degraded lands (Debashri \& Tamal, 2012), besides presenting a good regrowth ability after cutting, when developed in a saline-sodic soil treated with bovine biofertilizer. The plant grows adequately in non-saline soils, with biofertilizer, irrigated with growing salinity waters (Mesquita et al., 2015); and is moderately tolerant to salinity (Ayers \& Westcot, 1999). Finally, when considering the rusticity of the crop and the action of the biofertilizer in attenuating the damaging effects of the irrigation water salinity on the plants (Lima Neto et al., 2018), studies related to the water with saline restriction, in the soil with biofertilizer, shall contribute to the usage of the neem in reforestation activities of semiarid lands degraded by salinity, in the state of Paraiba.

With the exposed, the aim of this work was to evaluate the effects of the irrigation water salinity in the soil with and without bovine biofertilizer over the relative growth of neem (Azadirachta indica L.).

\section{Material and Methods}

The experiment was performed in the period from January to July of 2016, in a protected environment of the Department of Soils and Rural Engineering, Agrarian Sciences Center (CCA), Federal University of Paraiba (UFPB), located in the city of Areia, PB state, Brazil, georeferenced by the cartographic coordinates: 6 $6^{\circ} 51^{\prime} 47^{\prime \prime}$ and

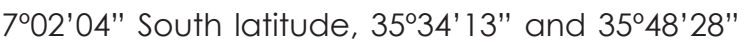
of West longitude from the prime meridian (Greenwich), with elevation of $575 \mathrm{~m}$ above sea level.

The average temperature of the region is $25.5^{\circ} \mathrm{C}$, average relative humidity of $71.7 \%$, with maximum value in May, of $85 \%$, and minimum value of $60 \%$, in January. In the hottest period of the experiment, the highest temperature registered in the inside of the screened shelter was in the month of January, with average value around $47.7^{\circ} \mathrm{C}$ and minimum value of $33.5^{\circ} \mathrm{C}$. The climate of the region is classified as As' (tropical savannah climate), with annual average precipitation of $1230 \mathrm{~mm}$ and a rainy season characterized in the period from March to July or until August (Alvares et al., 2014). In this same period, the air relative humidity varied within 44 and $57 \%$. These average values were obtained through monthly readings in the dry and rainy periods.

The soil of the experimental area, according with the criteria of the Brazilian Soil Classification System - SiBCS (Embrapa, 2013), was characterized as dystrophic Red-Yellow Latosol, of sandy texture, non-saline, collected in 
the first $20 \mathrm{~cm}$ of depth. After the collection, the soil samples were grinded and passed through a $2 \mathrm{~mm}$ mesh sieve (ADFE), and characterized in the physical and chemical attributes regarding salinity, by employing the methodologies compiled by Embrapa (2017). The soil samples were yet characterized as to the salinity of the saturation extract, according to Richards (1954), and the results are presented in Table 1.

Table 1. Chemical, physical, and salinity characterization of the soil in the 0-20 cm depth. Areia, PB state, 2016.

\begin{tabular}{|c|c|c|c|c|c|}
\hline $\begin{array}{c}\text { Ferfility } \\
\text { attributes }\end{array}$ & Value & Physical attributes & Value & Salinity attributes & Value \\
\hline $\mathrm{pH}$ in water $(1: 2,5)$ & 6.5 & Ds $\left(\mathrm{g} \mathrm{cm}^{-3}\right)$ & 1.55 & $\mathrm{ECe}\left(\mathrm{dS} \mathrm{m}^{-1}\right)$ & 0.71 \\
\hline $\operatorname{SOM}\left(\mathrm{g} \mathrm{kg}^{-1}\right)$ & 12.2 & $\mathrm{Dp}\left(\mathrm{g} \mathrm{cm}^{-3}\right)$ & 2.57 & $\mathrm{pH}$ & 7.11 \\
\hline$P\left(\mathrm{mg} \mathrm{dm}^{-3}\right)$ & 28.6 & $\mathrm{Pt}\left(\mathrm{m}^{3} \mathrm{~m}^{-3}\right)$ & 0.47 & $\mathrm{Ca}^{2+}\left(\mathrm{mmol}_{\mathrm{c}} \mathrm{L}^{-1}\right)$ & 1.91 \\
\hline $\mathrm{K}^{+}\left(\mathrm{mg} \mathrm{dm}^{-3}\right)$ & 116 & Sand $\left(\mathrm{g} \mathrm{kg}^{-1}\right)$ & 864 & $\mathrm{Mg}^{2+}\left(\mathrm{mmol}_{\mathrm{c}} \mathrm{L}^{-1}\right)$ & 1.22 \\
\hline $\mathrm{Ca}^{+2}\left(\mathrm{cmol}_{\mathrm{c}} \mathrm{dm}^{-3}\right)$ & 1.5 & Silt $\left(\mathrm{g} \mathrm{kg}^{-1}\right)$ & 65 & $\mathrm{Na}^{+}\left(\mathrm{mmol}_{\mathrm{c}} \mathrm{L}^{-1}\right)$ & 3.32 \\
\hline $\mathrm{Mg}^{+2}\left(\mathrm{cmol}_{\mathrm{c}} \mathrm{dm}^{-3}\right)$ & 0.8 & Clay $\left(\mathrm{g} \mathrm{kg}^{-1}\right)$ & 88 & $\mathrm{~K}^{+}\left(\mathrm{mmol}_{\mathrm{c}} \mathrm{L}^{-1}\right)$ & 1.09 \\
\hline $\mathrm{Na}^{+}\left(\mathrm{cmol}_{\mathrm{c}} \mathrm{dm}^{-3}\right)$ & 0.3 & $\operatorname{CDW}\left(\mathrm{g} \mathrm{kg}^{-1}\right)$ & 16 & $\mathrm{Cl}^{-}\left(\mathrm{mmol}_{\mathrm{c}} \mathrm{L}^{-1}\right)$ & 5.12 \\
\hline $\mathrm{H}^{+}+\mathrm{Al}^{+3}\left(\mathrm{cmol}_{\mathrm{C}} \mathrm{dm}^{-3}\right)$ & 1.1 & $\mathrm{DF}(\%)$ & 84.79 & $\mathrm{CO}_{3}^{2-}\left(\mathrm{mmol}_{\mathrm{c}} \mathrm{L}^{-1}\right)$ & - \\
\hline $\mathrm{Al}^{+3}\left(\mathrm{cmol}_{\mathrm{c}} \mathrm{dm}^{-3}\right)$ & 0.0 & ID (\%) & 15.44 & $\mathrm{HCO}_{3}^{-}\left(\mathrm{mmol}_{\mathrm{c}} \mathrm{L}^{-1}\right)$ & 1.42 \\
\hline $\mathrm{SB}\left(\mathrm{cmol}_{\mathrm{c}} \mathrm{dm}^{-3}\right)$ & 2.7 & $\mathrm{H}_{\mathrm{fc}}\left(\mathrm{g} \mathrm{kg}^{-1}\right)$ & 10.23 & $\mathrm{SO}_{4}{ }^{2-}\left(\mathrm{mmol}_{\mathrm{C}} \mathrm{L}^{-1}\right)$ & 0.99 \\
\hline $\operatorname{CEC}\left(\mathrm{cmol}_{\mathrm{c}} \mathrm{dm}^{-3}\right)$ & 4.2 & $H_{p w p}\left(g k^{-1}\right)$ & 4.45 & SAR $\left(\mathrm{mmol} \mathrm{L}^{-1}\right)^{1 / 2}$ & 2.67 \\
\hline$\vee(\%)$ & 69.9 & $\mathrm{Aw}\left(\mathrm{g} \mathrm{kg}^{-1}\right)$ & 5.66 & ESP $(\%)$ & 7.14 \\
\hline
\end{tabular}

Plastic containers with base diameter of $26.1 \mathrm{~cm}$ and $37 \mathrm{~cm}$ of height, with maximum capacity of $20 \mathrm{dm}^{-3}$, were utilized with $15 \mathrm{dm}^{-3}$ of substrate. In the base, a $2 \mathrm{~cm}$ layer of coarse gravel ( $n^{\circ}$. 20) was placed, and another layer of the same thickness of fine sand, washed with non-saline water. Each experimental unit was constituted of only one vigorous neem plant per plastic container or experimental parcel, obeying the system of standardization of the seedlings.

The treatments were distributed in randomized blocks, with four replications, in a $5 \times 2 \times 3$ factorial scheme, referring to five salinity levels in the irrigation water: $0.5 ; 1.5 ; 3.0 ; 4.5$ and $6.0 \mathrm{dS} \mathrm{m}^{-1}$, in the soil with and without bovine biofertilizer, in the liquid form, for the evaluation of the growth effects in height and stem diameter, evaluated in the periods of 90,120 and 180 days after the emergence of the seedlings. Still in these periods, the root, dry matter of the aerial part and total dry matter were quantified, corresponding to the sum of the two variables in each evaluation period, until reaching 180 DAE.

The irrigation of the treatments was daily performed, with sufficient water volume to elevate soil humidity to the field capacity level, and by registering every volume applied. These irrigations were performed with non-saline $(E C W=$
$0.5 \mathrm{dS} \mathrm{m}^{-1}$ ) and saline waters (ECW $=1.5 ; 3.0 ; 4.5$; $6.0 \mathrm{dS} \mathrm{m}^{-1}$ ), and every 15 days soil washings were performed with each type of water utilized in the irrigation of the plants.

The waters utilized for the irrigation of the neem seedlings were obtained by diluting a highly saline water (7.36 dS $\left.\mathrm{m}^{-1}\right)$, collected from the "jacarezinho" dam, placed in the city of Remigio - PB state, located at $22.4 \mathrm{~km}$ from the city of Areia. The value of the electrical conductivity for each type of irrigation water utilized in the experiment was obtained through the dilution of this highly saline dam water with non-saline and non-chlorinated water, of electrical conductivity

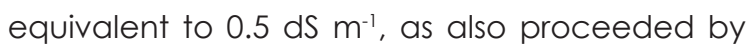
Mesquita et al. (2015). In the preparing of the four water treatments of different saline compositions, a portable electrical conductivity meter, Hi98304 model, Hanna manufacturer, was utilized in the successive measurements and in the control of the electrical conductivities of the waters.

The obtainment process of the bovine biofertilizer consisted of the anaerobic fermentation of a mixture of equal parts of fresh manure from lactating cows and water (nonsaline, non-chlorinated), in a biodigester with maximum capacity for $200 \mathrm{~L}$, during a period of 30 days (Mesquita et al., 2012a). For the maintaining 
of the hermetically closed system, one extremity of a $4 \mathrm{~mm}$ diameter hose was connected in the superior base of the biodigester, and the other was immersed in a bottle-like PET recipient of $2 \mathrm{~L}$, containing water. After the fermentative process, two days before sowing, the bovine biofertilizer was diluted in water in the proportion of $1: 1$, and applied in a volume equivalent to $10 \%$ of the substrate volume $\left(15.0 \mathrm{dm}^{-3}\right)$. For being provided in the liquid form, the biofertilizer was evaluated as if it were irrigation water, and it presented the following values: $\mathrm{Ca}^{2+}=1.16, \mathrm{Mg}^{2+}=0.69, \mathrm{Na}^{+}=$ $2.47, \mathrm{~K}^{+}=0.18, \mathrm{Cl}^{-}=3.48 ; \mathrm{HCO}_{3}=0.29, \mathrm{SO}^{-2}=0.72$ $\mathrm{mmol}_{\mathrm{c}} \mathrm{L}^{-1}$, electrical conductivity at $25{ }^{\circ} \mathrm{C}=3.41$ $\mathrm{dS} \mathrm{m}^{-1}$ and $\mathrm{pH}=6.72$ (Richards, 1954).

In each experimental unit, five neem seeds (Azadirachta indica A. Juss) were sowed, with viability of $89 \%$. At 30 days after emergence, the thinning of the seedlings was performed, allowing only one vigorous seedling per vessel.

After sowing, the monitoring was performed in order to record the first counting of normal seedlings emerged, and daily counts were performed until the process of emergence for the evaluation of the biometric variables. In the periods of 60,120 and 180 days after emergence of the seedlings (DAE), the plant height was measured with a millimetric scale, and the stem diameter was measured with a digital pachymeter. At 180 DAE, the values of root, aerial part and total (root + aerial part) dry matter were obtained after the drying of the material in a forced-air drying oven, until constant weight (Mesquita et al., 2012b).

The seedlings growth was computed based on the data of plant height, stem diameter, dry matter of the aerial part, root dry matter and total dry matter, thus obtaining the relative growth concerning plant height, stem diameter, dry matter of the aerial part and total dry matter of the neem seedlings, evaluated by the relation of the periods of 90,120 and $180 \mathrm{DAE}$, according to the bellow-described equations, in order to evaluate the relations of these periods over each studied variable, from 90 to 120 and from 120 to 180 days after emergence of the seedlings. The utilized formula for the determination of the relative growth rate was according to Mesquita et al. (2012b), being: RGR $=(\ln (\mathrm{V} 2)-\ln (\mathrm{V} 1)) /(\mathrm{T} 2-$
T1), in which, based on every studied period, the parameter indicated by $(\mathrm{V})$ means the variable in study, and (T) is the time of each period, respectively.

The data were subjected to analysis of variance by the $\mathrm{F}$ test, and regression analysis for the salinity levels (Banzatto \& Kronka, 2008). For the processing of the data, the SISVAR ${ }^{\oplus}$ demonstrative software was utilized (Barbosa et al., 2015).

\section{Results and Discussion}

In spite of the expressive superiority at 180 days (Period 3), the growth analysis of the neem seedlings, if compared with the Period 1 (at 90 days after emergence), presented a strong variation in the growth in height, obtaining a highest value of $0.0032 \mathrm{~cm} . \mathrm{cm}^{-1}$ Time $^{-1}$ in the estimated salinity of $2.5 \mathrm{dS} \mathrm{m}^{-1}$. In the second evaluation period, at 120 days after emergence, the neem seedlings did not present any interference in the relative growth in height, regardless of the studied period, admitting an average value $0.041 \mathrm{~cm} . \mathrm{cm}^{-1}$ Time '. At the end of the experiment, at 180 days after emergence (DAE), the relative growth in height of the neem seedlings decreased until the estimated salinity of $3.5 \mathrm{dS} \mathrm{m}^{-1}$; from this value, the plants responded positively with the increment of the saline content until the estimated electrical conductivity of the irrigation water of $6.0 \mathrm{dS} \mathrm{m}^{-1}$, with $91.18 \%$ of statistical reliability (Figure 1). The relative growth (RG) refers to how fast a plant grows when compared to its initial size.

The values are in consonance with Silva et al. (2008), where the RGR decreases as the plant grows, due to, among other factors, the increase in the intraspecific competition for the main environmental factors responsible for plant growth. Effectively, the most striking effects of salinity over the plant reflect in alterations of the osmotic potential, in the ionic toxicity, and in the unbalance of nutrient absorption, leading to a generalized reduction in growth, with serious damages to the agricultural activity (Karan \& Subudhi, 2012).

Regardless of the application of biofertilizers and the periods in the seedlings, the values for stem diameter, in the treatments without the organic input, did not adjust to any 
mathematical model, being represented by the average value of $0.012 \mathrm{~cm} . \mathrm{cm}^{-1}$ Time $^{-1}$ (Figure 2), although the results referring to the treatments with biofertilizer and addition of waters with growing salinity do overcome those treatments which did not receive the organic input in the soil, in both evaluation periods.

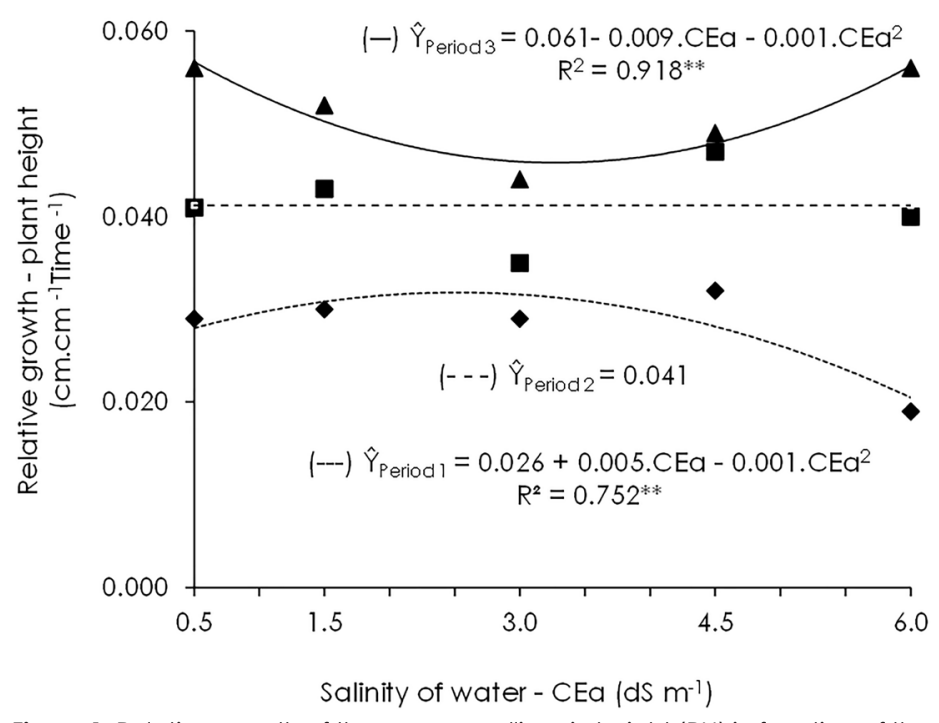

Figure 1. Relative growth of the neem seedlings in height (PH) in function of the salinity of the irrigation water, evaluated in the periods from $90(--), 120(-.-)$ and 180 DAE (-). CCA/UFPB, Areia-2016.

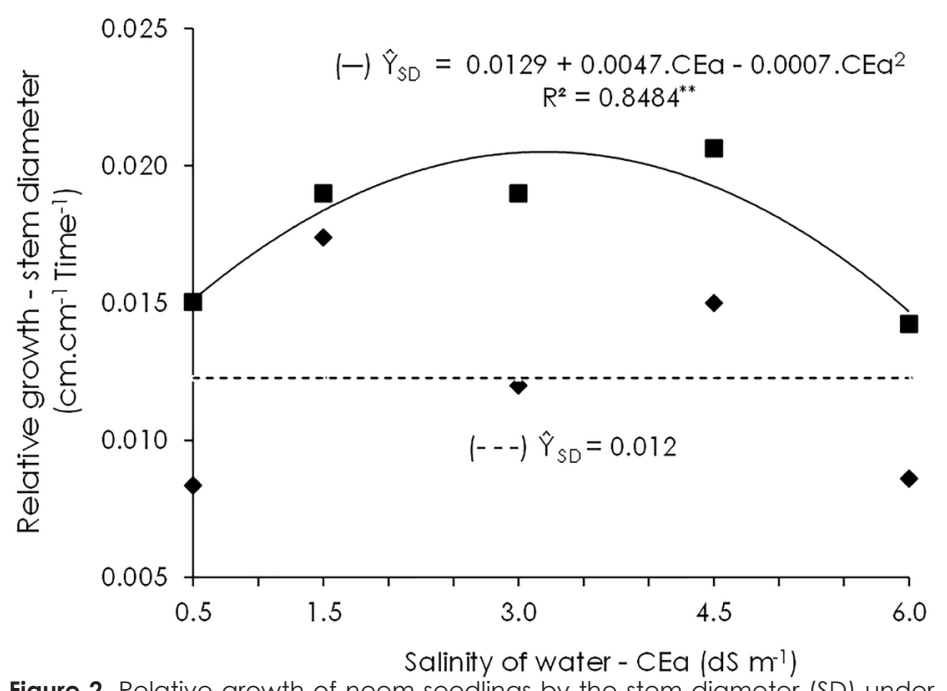

Figure 2. Relative growth of neem seedlings by the stem diameter (SD) under irrigation with saline waters, in soil without (- - -) and with (-) bovine biofertilizer, evaluated by the average values of the periods from 60 to 120 and from 120 to 180 DAE, CCA/UFPB, Areia-2016.

By performing a comparative analysis of the treatments without and with the organic input, an elevated dispersion of these data might be perceived, due to the stress caused by the salinity of the waters (Figure 2). In spite of this high expressivity of the data, and due to the stress caused by the salinity of the waters, a drastic inhibition of the plants occurred, caused by the degenerative effects of the salts, from the saline content of $3.35 \mathrm{dS} \mathrm{m}^{-1}$, over the stem diameter in the soil with biofertilizer, that is, the saline stress significantly reduced the neem seedlings growth from 0.020 to $0.015 \mathrm{~cm} . \mathrm{cm}^{-1}$ Time $^{-1}$ ( 3.35 and 6.0 dS $\mathrm{m}^{-1}$, respectively), due to the direct effects of the ions toxicity or to indirect effects of the saline ions present in the soil, causing osmotic unbalances to the plants (García et al., 2011).

When comparing the results within the situations of the same substrate, it is observed that in spite of the superiority of the soil with bovine biofertilizer, the seedlings suffered a decline of $0.002 \mathrm{~mm}$ for each unitary increase of 
the electrical conductivity of the irrigation water.

When considering that the tolerance of the plants to salinity is evaluated by the results of the roots interaction with the saline environment (Maas \& Hoffmann, 1977), and that the neem is moderately tolerant to salinity, according to Ayers \& Westcot (1999), the irrigation with waters that offer moderate ( $E C W>3.0 \mathrm{dS} \mathrm{m}^{-1}$ ) or severe ( $E C W$ $>6.0 \mathrm{dS} \mathrm{m}^{-1}$ ) restrictions might compromise the production of quality seedlings for transplanting.

The data are inferior to the $0.025 \mathrm{~cm} . \mathrm{cm}$ 'day'-1 presented by Mesquita et al. (2012b), when studying the effect of the irrigation water salinity over the indices of growth analysis in wingedstem passion flower (Passiflora alata) in soil with biofertilizer at 60 DAE.

The relative growth of the root dry matter of the neem seedlings was significantly influenced by the interaction salinity $x$ biofertilizer, and through the observation of this growth analysis it was verified that the seedlings in the

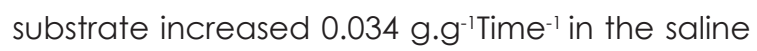
environment $\left(0.5 \mathrm{~d}^{-1} \mathrm{~m}^{-1}\right)$, reaching its higher value of $0.042 \mathrm{~g} . \mathrm{g}^{-1} \mathrm{Time}^{-1}$ in the estimated electrical conductivity of $6.0 \mathrm{dS} \mathrm{m}^{-1}$, that is, in the soil with common biofertilizer applied one week after germination. When evaluating the average value of the periods (from 60 to 120 and from 120 to 180 ), the seedlings evaluated by the treatments without biofertilizer suffered a reduction in the average root growth, from 0.0029 to $0.0027 \mathrm{~g} . \mathrm{g}$ 'Time', with a percentage decrease of $7.40 \%$ regarding the saline character 0.5 and $6.0 \mathrm{dS} \mathrm{m}^{-1}$, respectively (Figure 3).

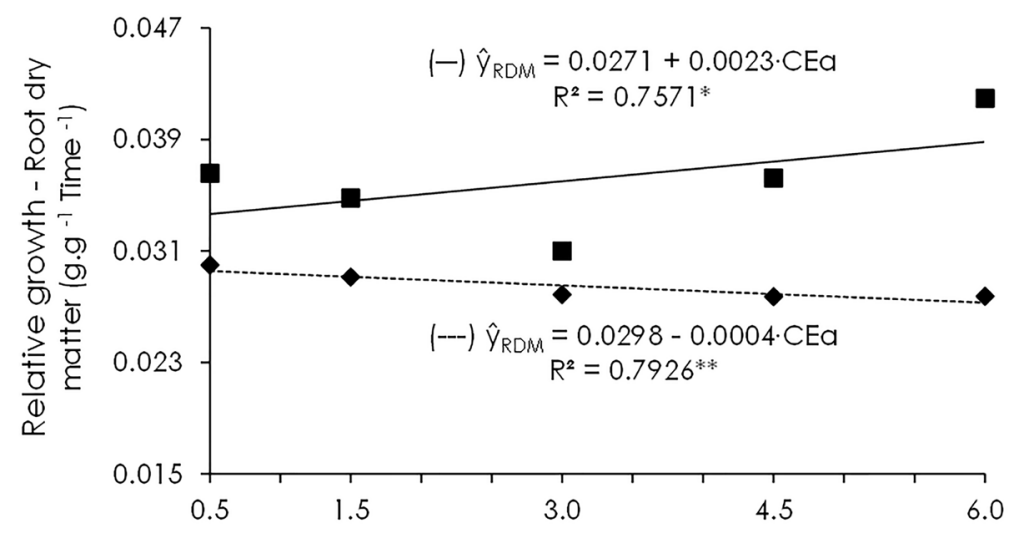

Salinity of water - CEa (as $\left.\mathrm{m}^{-1}\right)$

Figure 3. Relative growth of neem seedlings evaluated by the root dry matter (RDM) irrigated with waters of growing salinity, in soil without (- - -) and with (-) bovine biofertilizer, tested by the average values of the periods (from 60 to 120 and from 120 to 180 DAE), CCA/UFPB, Areia-2016.

As the saline contents increased in the irrigation waters of the soil with the organic input, the relative growth of the seedlings, referring to the dry matter of the aerial part, did not verify any inhibition, in the growth and development of the neem seedlings. The behaviors of these data corroborate with the results reported by Mesquita et al. (2015) and Mesquita et al. (2017), in studies with Indian neem (Azadirachta indica A. Juss), and Mexican mint (Plectranthus amboinicus L.). A similar situation was also verified in passion fruit at $60 \mathrm{DAE}$, that is, the relative growth of the root phytomass was inhibited from 0.042 to 0.018 $\mathrm{cm} . \mathrm{cm}^{1}$. day $^{-1}$ in the lowest and highest salinity levels $\left(0.5\right.$ and $\left.6.0 \mathrm{dS} \mathrm{m}^{-1}\right)$, respectively in the soil without and with bovine biofertilizer (Mesquita et al., 2012b).

At the end of the experiment, at 180 DAE, without interference of the factor age of the seedlings, the behavior of the data referring to the relative growth of the aerial part of the neem seedlings was negatively affected by the salts present in the water, superior to $3.71 \mathrm{dS} \mathrm{m}^{-1}$ in the soil without the fermented bovine biofertilizer, that is, after this point, the seedlings ceased their relative growth, oscillating from 0.039 to 0.032 g.g.-1Time ${ }^{-1}$ with saline levels of 3.71 and 6.0 dS $\mathrm{m}^{-1}$. However, in the same evaluation period, with the utilization of the organic input, the neem seedlings did not present inhibition in the relative growth of the aerial part under supplementary irrigation with saline waters $\left(0.5\right.$ to $\left.6.0 \mathrm{dS} \mathrm{m}^{-1}\right)$ 
admitting its highest value in phytomass of aerial part to $0.050 \mathrm{~g}^{\mathrm{g}} \mathrm{g}^{-1} \mathrm{Time}^{-1}$ (Figure 4).

Literature cites that the reduction in the leaf area is an important adaptive mechanism of plants cultivated under salt excess and hydric stress, seen that, under such conditions, it is convenient for the plants to start the reduction of the transpiratory process and, consequently, to decrease the loading of $\mathrm{Na}^{+}$and $\mathrm{Cl}^{-}$in the xylem and the conservation of water in the plant tissues, according to no (Sucre \& Suáres, 2011).

From the agronomical point of view, the increase in the root length might strength the entire morphological structure of the plants, thus allowing to obtain fit seedlings for the field transplanting in a shorter period of time (Natale et al., 2004).

The values relative to the relative growth analysis of the total dry matter in the neem seedlings were positively influenced by the interaction water salinity $x$ biofertilizer, and express superiority in the treatments with biofertilizer (Figure 5).

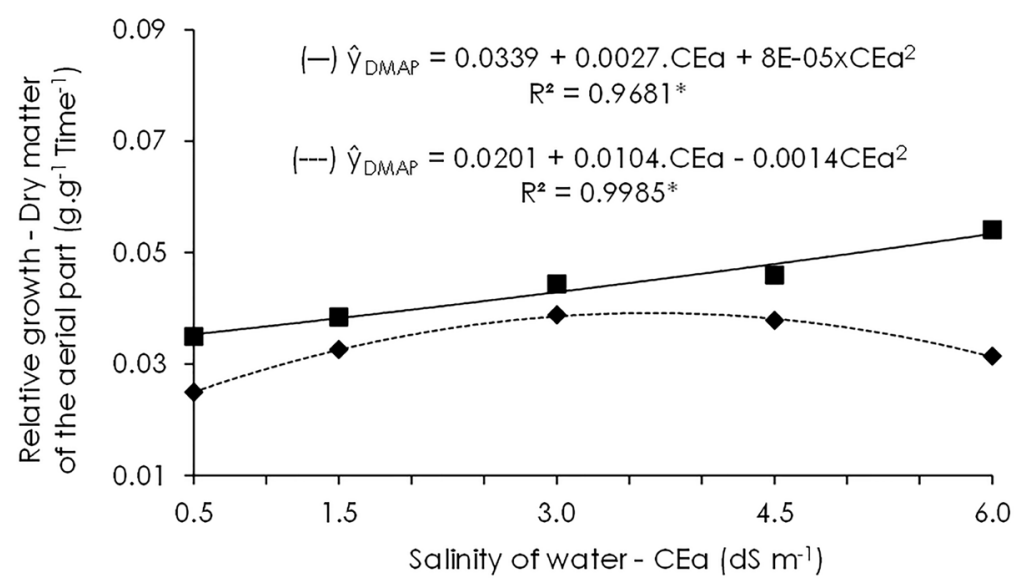

Figure 4. Relative growth of neem seedlings evaluated by the dry matter of the aerial part (DMAP) under irrigation with saline waters, in soil without (---) and with (-) bovine biofertilizer, analyzed by the averages values in the periods from 60 to 120 and from 120 to 180 DAE, CCA/UFPB, Areia-2016.

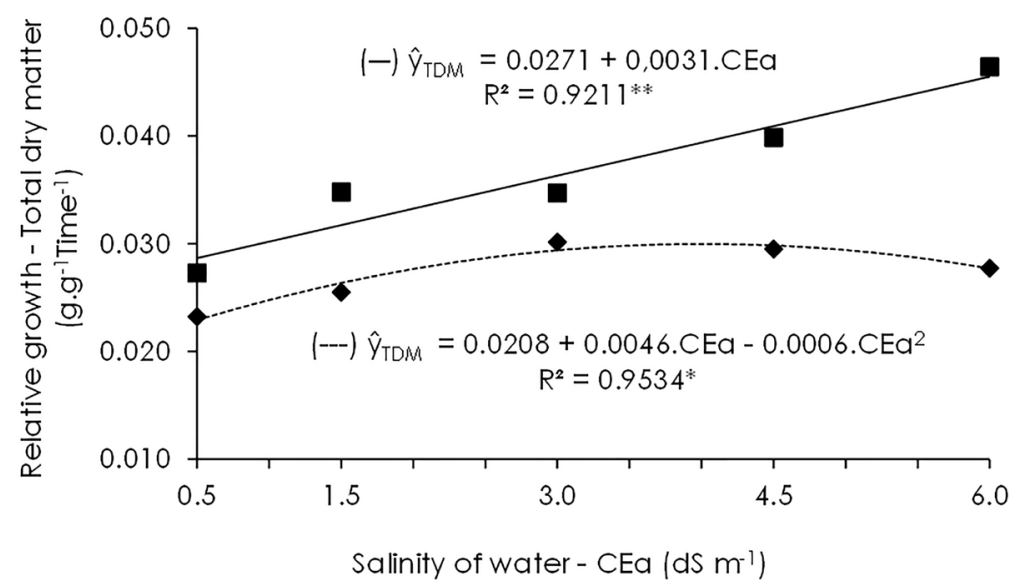

Figure 5. Relative growth of neem seedlings by the total dry matter (TDM) under irrigation with saline waters, in soil without (--) and with (-) bovine biofertilizer, quantified by the average values in the periods from 60 to 120 and from 120 to 180 DAE, CCA/UFPB, Areia-2016.

The relative growth of the neem seedlings, evaluated as to the TDM, suffered variation of 0.029 and $0.045 \mathrm{~g} \mathrm{~g}^{-1} \mathrm{Time}^{-1}$, without interference of any studied period, but with effects in the soils without and with organic input, seen that both situations correspond to an estimated water electrical conductivity of 3.83 and $6.0 \mathrm{dS} \mathrm{m}^{-1}$. Such a fact demonstrates that the biofertilizer provides positive effects over the growth and development of the plants, besides contributing to the improvement of the soil, stimulating the microbiota, producing 
proline, glycine, nucleic acids and membranes, combined to other existing elements in the own biofertilizer composition, resulting in a higher osmotic adjustment (Liang et al., 2005; Boraste et al., 2009).

A similar behavior was also presented by Rebequi et al. (2009) when evaluating the production of Rangpur seedlings in substrate with bovine biofertilizer, irrigated with saline waters. The authors verified that the root dry matter was compromised in function of the salinity of the irrigation waters, but always in lower intensity in the treatments with the bovine biofertilizer.

\section{Conclusions}

The relative growth in height and stem diameter, at 60, 120 and 180 days after emergence (DAE) and the root, shoot and total phytomass, at $180 \mathrm{DAE}$, responded positively to the bovine biofertilizer.

The bovine biofertilizer mitigates but does not eliminate the degenerative effects of the excess of salts in the irrigation water on neem seedlings.

The increase in the salinity of the irrigation

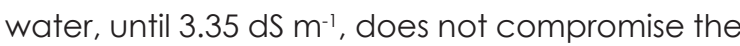
relative growth of the seedlings in the treatments with the bovine biofertilizer.

\section{Acknowledgments}

To the Conselho Nacional de Desenvolvimento Científico e Tecnológico (CNPq), to the Fundação de Amparo à Pesquisa do Estado da Paraíba (FAPESQ/PB), to the Coordenação de Pessoal de Ensino Superior (CAPES) and to the Instituto Nacional de Ciência e Tecnologia em Salinidade (INCTSal), respectively for the project financing and for the concessions of the scholarships.

\section{References}

Alvares, C.A., Stape, J.L., Sentelhas, P.C., Gonçalves, J.L.M., Sparovek, G. 2014. Köppen's climate classification map for Brazil. Meteorol Zeitschrift 22: 711-728.

Ayers, R. S., Westcot, D.W. 1999. A qualidade de água na agricultura. 2. ed. UFPB, Campina Grande, Brazil. 153 p. (FAO - Estudos Irrigação e Drenagem, 29)

Banzatto, D.A., Kronka, S.N. Experimentação agrícola. 4. ed. UNESP, Jaboticabal, Brazil. 247 p.

Barbosa, J.C., Maldonado Junior, W. 2015. AgroEstat - sistema para análises estatísticas de ensaios agronômicos. FCAV/UNESP, Jaboticabal, Brazil. 396 p.

Boraste, A., Vamsi, K. K., Jhadav, A., Khairnar, Y., Gupta, N., Trivedi, S., Patil, P., Gupta, G., Gupta, M., Mujapara, A. K., Joshi, B. 2009. Biofertilizers: A novel tool for agriculture. International Journal of Microbiology Research 1: 23-31.

Debashri, M., Tamal, M. 2012. A review on efficacy of azadirachta indica a. juss based biopesticides: an Indian perspective. Research Journal of Recent Sciences 1: 94-99.

Dutra, T.R., Massad, M.D., Santana, R.C. 2012. Parâmetros fisiológicos de mudas de copaíba sob diferentes substratos e condições de sombreamento. Ciência Rural 42: 1212-1218.

Embrapa. 2017. Centro Nacional de Pesquisa de Solos. Manual de métodos de análise do solo. $3^{a}$ ed. EMBRAPA, Rio de Janeiro, Brazil. 573p. (Embrapa - CNPS. Documentos, 1)

Embrapa. 2013. Centro Nacional de Pesquisa de Solos. Sistema brasileiro de classificação de solos. $3^{a}$. ed. Embrapa Solos, Brasília, Brazil. 353 p.

García, B.L., Alcántara, L.P., Fernández, J.L.M. 2011. Soil tillage effects on monovalent cations $\left(\mathrm{Na}^{+}\right.$and $\left.\mathrm{K}^{+}\right)$in vertisols soil solution. Catena 84: 61-69.

Isla, R., Guillén, M., Aragüés, R. 2014. Response of five tree species to salinity and water logging: Shoot and root biomass and relationships with leaf and root ion concentrations. Agroforestry Systems 88: 461-477.

Karan, R., Subudhi, P.K. 2012. approaches to increasing salt tolerance in crop plants. Irrigation Science 30: 63-88.

Katerji, N., Mastrorilli, M., Lahmar, F. 2011. FAO-56 methodology for the stress coefficient evaluation under saline environment conditions: Validation on potato and broad bean crops. Agricultural Water Management 98: 588-596.

Klippel, V.H., Pezzopane, J.E.M., Pezzopane, J.R.M., Cecílio, R.A., Castro, F.S., Pimenta, L.R. 2013. Zoneamento climático para teca, cedro australiano, nim indiano e pupunha no estado do Espírito Santo. Floresta 43: 671-680.

Liang, Y.C., Si, J., Nikolic, M., Peng, Y., Cheng, W., Jiang, Y. 2005. Organic manure stimulates biological activity barley growth in soil subject to secondary salinization. Soil Biology and biochemistry 37: 1185-1195. 
Lima Neto, A.J., Cavalcante, L.F., Nunes, J.C., Souto, A.G.L., Bezerra, F.T.C., Cavalcante, A.G. 2018. Biometric variables and photosynthetic pigments in tamarind seedlings irrigated with saline water and biofertilizers. Semina: Ciências Agrárias 39: 1909-1920.

Lima, J.F. Peixoto, C.P., Ledo, C.A da S. 2007. Índices fisiológicos e crescimento inicial de mamoeiro (Carica papaya L.) em casa de vegetação. Ciência e Agrotecnologia 31: 13581363.

Maas, E.V., Hoffman, G.J. 1977. Crop salt tolerance current assessment. Journal of Irrigation and Drainage Division 103: 115-134.

Maithani, A., Parcha, V., Pant, G., Dhulia, I., Kumar, D. 2011. Azadirachta indica (neem) leaf: A review. Journal of Pharmacy Research 4: 18241827.

Medeiros, P.L., Silva, G.G.C., Pimenta, A.S., Oliveira, E.M.M., Duarte, L.C. 2017. Growth and distribution of fine roots of neem (Azadirachta indica) under two farming methods in the Northeast of Brazil. International Journal of Agriculture Sciences 9: 4020-4025.

Medeiros, R.F., Cavalcante, L.F., Rodrigues, R.M., Mesquita, F.O., Bruno, R.L.A., Ferreira Neto, M. 2013. Uso de biofertilizantes e águas salinas em plantas de Licopersicon pimpinellifolium L. Revista Brasileira de Ciências Agrárias 8: 156-162.

Mesquita, F.O., Cavalcante, L.F., Pereira, W.E., Rebequi, A.M., Lima Neto, A.J., Nunes, J.C. 2012 a. Produção de mudas de maracujazeiro amarelo submetidas à salinidade em solo com biofertilizante bovino. Revista Ciencia del Suelo 30: $31-41$.

Mesquita, F.O., Rebequi, A.M., Cavalcante, L.F., Souto, A.G.L. 2012b. Crescimento absoluto e relativo de mudas de maracujazeiro sob biofertilizante e águas salinas. Revista de Ciências Agrárias 30: 222-239.

Mesquita, F.O., Cavalcante, L.F., Nunes, J.C., Luna Souto, A.G., Medeiros, R.F., Rodrigues, R.M. 2015. Formação de mudas de nim com aplicação de biofertilizante bovino submetido à drenagem e estresse salino. Bioscience Journal 31: 47-51.

Mesquita, S.B.S., Costa, R.S., A.V., Amorin, A.V., Lacerda, C.F., Fonseca, A.M., A.M. 2017. Crescimento e composição do óleo essencial de malvariço cultivado sob salinidade e doses de biofertilizante. Revista Agro@mbiente 11:315322.

Munns, R., Tester, M. 2008. Mechanisms of Salinity Tolerance. Annuario journal Plant Biology 59: 65181.
Natale, W., Prado, R. M., Leal, R.M., Franco, C.F. 2014. Efeitos da aplicação de zinco no desenvolvimento, no estado nutricional e na produção de matéria seca de mudas de maracujazeiro. Revista Brasileira de Fruticultura 26: $310-314$.

Neves, E.J.M., Carpanezzi, A.A. 2008. O Cultivo do nim para produção de frutos no Brasil. Embrapa Florestas, Colombo, Brazil. 8 p. (Circular Técnica, 162)

Rebequi, A.M., Cavalcante, L.F., Nunes, J.C., Diniz, A.A., M. A. S Brehm, M.A.S., BeckmannCavalante, M.Z. 2009. Produção de mudas de limão cravo em substrato com biofertilizante bovino irrigado com águas salinas. Revista de Ciências Agrárias 32: 219-228.

Richards, L.A. 1954. Diagnosis and improvement of saline and alkaline soils. United States Salinity Laboratory Staff, Washington, USA.160 p. (Document Agriculture, 60).

Silva, J.C.P.M., Motta, A.C.V., Pauletti, V., Favaretto, N., Barcellos, M., Oliveira, A.S., Veloso, C.M., Silva, L.F.C. 2008. Esterco líquido de bovinos leiteiros combinado com adubação mineral sobre atributos químicos de um Latossolo Bruno. Revista Brasileira de Ciência do Solo 32: 25632572.

Sucre, B., Suáres, N. 2011. Effect of salinity and PEG-induced water stress on water status, gas exchange, solute accumulation, and leaf growth in Ipomoea pes-caprae. Environmental and Experimental Botany 70: 192-203.

Yang, J., Zhang, L., Hira, D., Fukuzaki, Y., Furukawa, K. 2011 . Anammox treatment of highsalinity wastewater at ambient temperature. Bioresource Technology 102: 2367-2372. 